\title{
ABO Genotyping from Pulp and Dentin Using DNA - A PCR Study
}

\author{
Jaya Lakshmi B. ${ }^{{ }^{*}}$ and Avinash Tejasvi M. L. ${ }^{2}$ \\ 'Senior Resident, Department of Oral Medicine and Radiology, Government Dental College, \\ Hyderabad, Telangana, India; drjayalakshmi1992@gmail.com \\ ${ }^{2}$ Professor, Department of Oral Medicine and Radiology, Kamineni Institute of Dental Sciences, \\ Narketpally, Telangana, India
}

\begin{abstract}
Background: Blood grouping has a major role in forensic science in the field of human identification. Aim of the Study: Aim of this study was to determine ABO genotyping from pulp and dentin using PCR method. Objectives: To determine PCR based blood grouping from the DNA isolated from tooth Pulp and Dentin. Materials and Meathods: Dental pulp tissue and Dentin was collected from 20 permanent teeth and DNA extraction was carried out from pulp using (modified proteinase -K method) and from dentin using phenol/chloroform(organic method). PCR procedure was carried out and samples were subjected to agarose gel electrophoresis and blood group was determined using specific PCR primers for ABO genotyping. Results: Among the 20 samples of pulp tissue, 17 samples showed accurate results in PCR method in comparison with slide agglutination method. Among the 20 samples of dentin, blood grouping from dentin was not possible as the quantity and purity of DNA from dentin samples were not optimal. Sensitivity of $85 \%$ and specificity of $50 \%$ was noticed from the samples of pulp. Conclusion: PCR was found to be an effective method in determination of blood group from teeth. Thus our study states that isolation of DNA can be done from both pulp and dentin and the blood grouping can be done from tooth pulp by PCR method. Hence PCR method can be used for identification of individuals which adds beneficiary value to forensic dentistry.
\end{abstract}

Keywords: ABO Genotyping, Blood Grouping, Dentin, Polymerase Chain Reaction, Pulp

Article chronicle: Date of Submission: 7.03.2019; Date of Acceptance: 22.01.2020; Date of Publication: 24.04.2020

\section{Introduction}

The term "forensic" is derived from the Latin word, which means a forum or a place where legal matters are discussed. ${ }^{1}$ The study of jaw and teeth as evidence in law and justice is called forensic dentistry. ${ }^{2}$ Forensic odontology or forensic dentistry is a branch of forensic medicine which, in the interest of justice, deals with the proper handling and examination of dental evidence with the proper evaluation and presentation of the dental evidence. ${ }^{3}$ The forensic importance of dental tissue has been well recognized because of the fact that tooth is the hardest of all human tissues in the body, and they can be preserved intact for a longer duration of time after the death. ${ }^{4}$ In the present day there is an increase in the crime rate against children, adults in the form of battering, sexual/physical abuse, abduction, and kidnapping. Teeth may be the source of evidence available at the crime scenes. The dental pulp available from tooth even though in minor quantity can prove to be highly useful. ${ }^{5}$ Blood groups have been the cornerstones for identification of biological materials in forensic medicine and science. ${ }^{6}$

Blood group determination in a medicolegal examination is based on the fact that once a group is determined in an individual, it remains unchanged throughout the life. Blood group substances have been detected from the dental pulp. Postmortem changes in dental pulp are seen very late, and also, pulp remains one of the most protected tissues and therefore could be readily available for examination. Establishing the blood group from the dental pulp can serve as a reliable antemortem and postmortem record. ${ }^{4}$ DNA analysis is

${ }^{*}$ Author for correspondence 
an important method used in forensic identification with a higher degree of certainty as compared to the other traditional methods used.

Blood group determination can be done from the dental pulp tissue using various methods such as hemagglutination, absorption elusion, and histochemical technique. Polymerase chain reaction (PCR) stands one step ahead above all the mentioned methods with a high rate of specificity and sensitivity. ${ }^{8}$

The uniqueness of the present study is determination of blood grouping from dental pulp through PCR method which is useful for identification of decayed bodies or skeletonized bodies which has been difficult with conventional methods. PCR amplification of specific alleles (PASA) method allows the simple and rapid detection of multiple single-nucleotide polymorphism (SNP) sites on the $\mathrm{ABO}$ gene and is useful for determining the ABO genotype. Mentioned base pairs can be taken as a standard for determining $\mathrm{ABO}$ genotyping from pulp which has been proved in the present study.

Previously, many studies have been done using conventional methods. To the best of our knowledge, this is the first study done by isolation of DNA from permanent tooth pulp and also determination of blood grouping (ABO genotyping) from dental pulp using PCR method.

\section{Objectives of the Study}

- Determination of ABO blood grouping by slide agglutination method on fresh blood collected from socket following the extraction of permanent teeth

- Isolation of DNA from tooth pulp

- Isolation of DNA from dentin

- Determination of ABO genotyping from the DNA isolated from tooth pulp

- Determination of ABO genotyping from the DNA isolated from dentin

- To compare the accuracy of slide agglutination on fresh blood and from DNA isolated from pulp and dentin.

\section{Methodology}

\section{Source of data}

The study sample was calculated using a formula by randomized, control, single-blinded study which included 20 extracted teeth, of which 7 were males and 13 were females. Blood grouping was done, and samples collected from the individuals who visited the Department of Oral and Maxillofacial Surgery, Kamineni Institute of Dental Sciences, were taken into the study.

\section{Inclusion criteria for the study group}

- Tooth samples from an age group within 18-45 years as the study was planned on only permanent teeth

- Permanent teeth which were extracted for orthodontic treatment purpose and impacted teeth were included

- Sound tooth or relatively intact tooth without any wear facets.

\section{Exclusion criteria for the study group}

- Deciduous teeth

- Teeth with wear facets, restored teeth, and endodontically treated teeth were excluded

- Teeth which are infected, fractured, or found with any developmental abnormality.

\section{Method}

The present study was an experimental randomized single-blinded study consisting of 20 extracted teeth [Figure 1] categorized into three groups: Group A is the control group, i.e. the group in which blood group is determined by slide agglutination method (from socket blood) consists of 20 samples [Figures 2 and 3]. Group B consists of 20 pulp samples [Figure 4]. Group C consists of 20 dentin samples [Figure 5]. Tooth samples were washed in $5.2 \%$ sodium hypochlorite solution for around

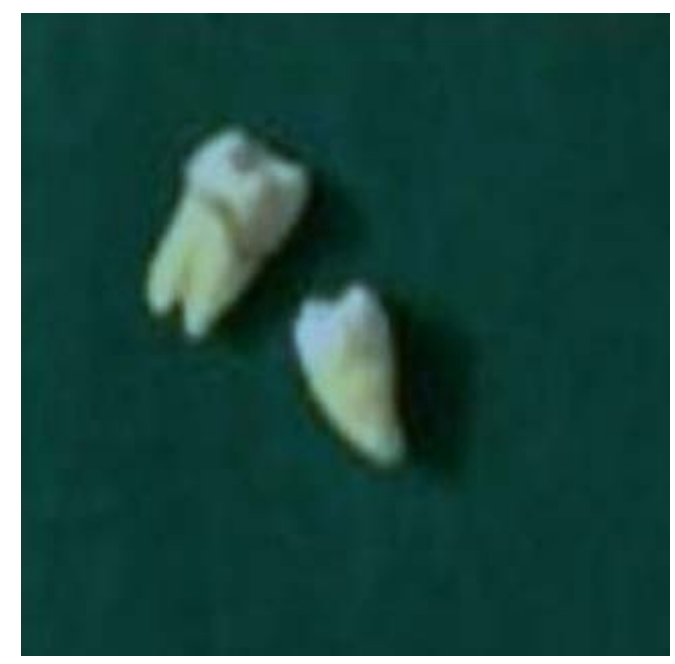

Figure 1: Freshly extracted tooth samples 


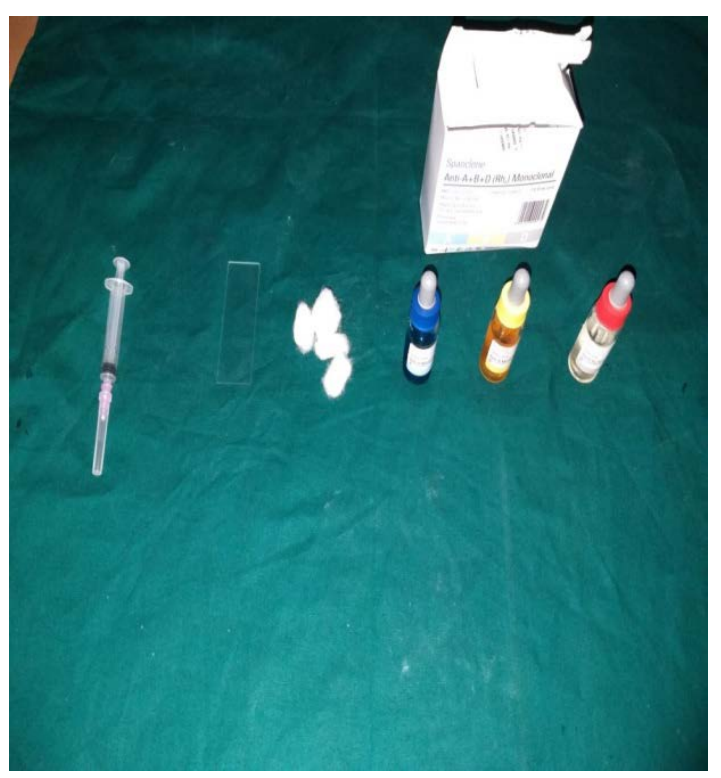

Figure 2: Antisera kit

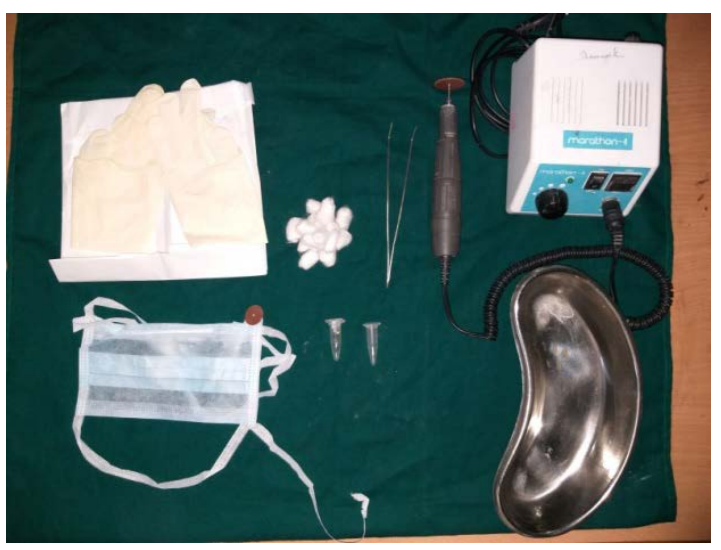

Figure 3: Armamentarium to derive pulp and dentin powder

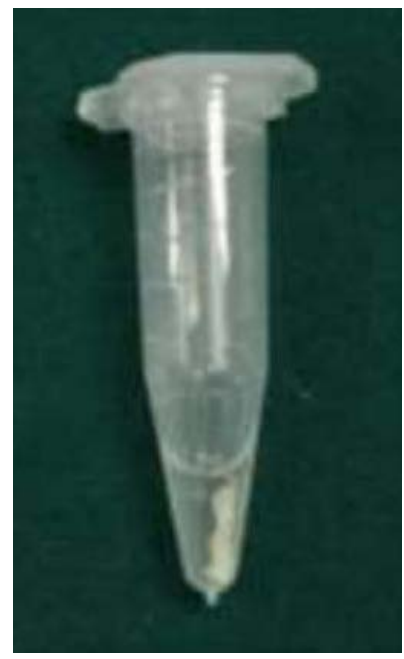

Figure 4: Pulp sample

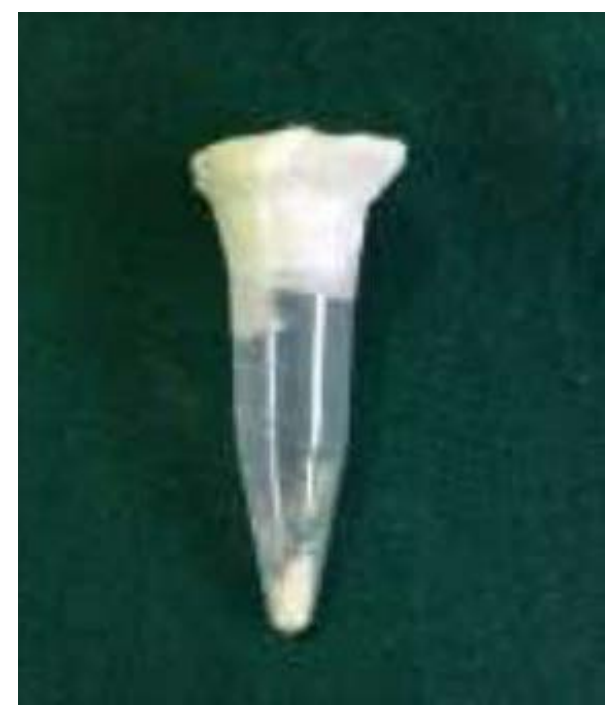

Figure 5: Dentin sample

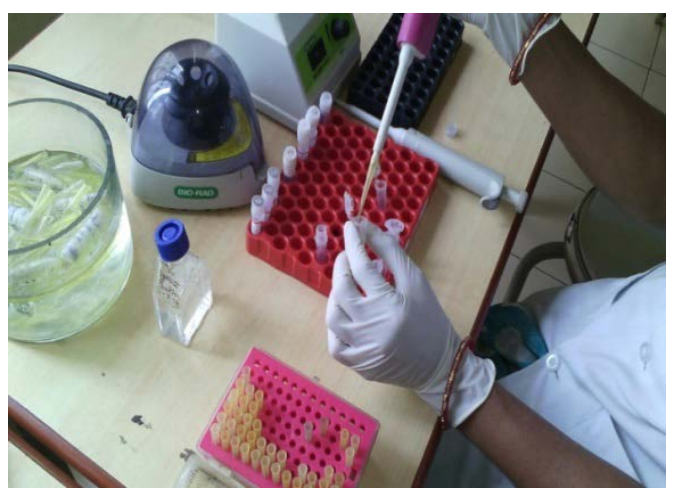

Figure 6: DNA extraction procedure (addition of ethylene diamine tetra-acetic acid)

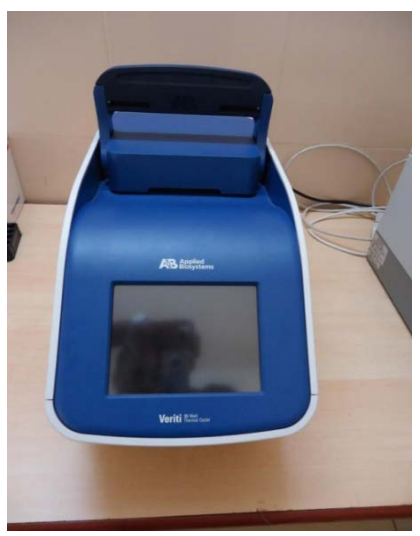

Figure 7: Polymerase chain reaction thermal cycler

$30 \mathrm{~s}$, and then, the teeth were cleaned and washed again with sterile distilled water for around $30 \mathrm{~s}$.

Two investigators were involved in determination of blood group from pulp and dentine in the study. Access 
opening was done on the collected teeth samples; dental pulp tissue was collected from each sample using a barbed broach no. 21 which was also cleaned with spirit after the usage for each tooth, and separate broaches were used for teeth samples. The derived pulp sample was then put in a sterile Eppendorf tube containing a DNA extraction buffer sodium dodecyl sulfate or sodium lauryl sulfate. The tubes were labeled accordingly and stored at normal room temperature.

Dentin powder was obtained using hand trimmer and straight fissure acrylic trimming bur. The powder was then collected into sterile Eppendorf tubes [Figure 5] and labeled accordingly and stored at normal room temperature.

Samples of both pulp and dentin were then sent to the department of molecular biology and immunology to the second observer who does not know the blood group of the patient for further procedure. In the next step, DNA extraction procedure was done using modified proteinase-K method for pulp and phenol/chloroform organic extraction method for dentin [Figure 6]. Later, PCR [Figure 7] was done in which the following set of O-261N,ABO-1R3,ABO-1FAB2,ABO-1R, fy-43,526$\mathrm{B} 2,526-\mathrm{A}, \mathrm{Fy}-2 \mathrm{PCR}$ primers were used which is specific to blood group. After PCR procedure, agarose gel electrophoresis was done [Figure 8]. Bands of specific sizes were identified by comparing the band sizes of DNA ladder.

\section{Analysis}

The gel was visualized under ultraviolet transilluminator. The target region from the DNA of each sample will be amplified and separated on the agarose gel depending

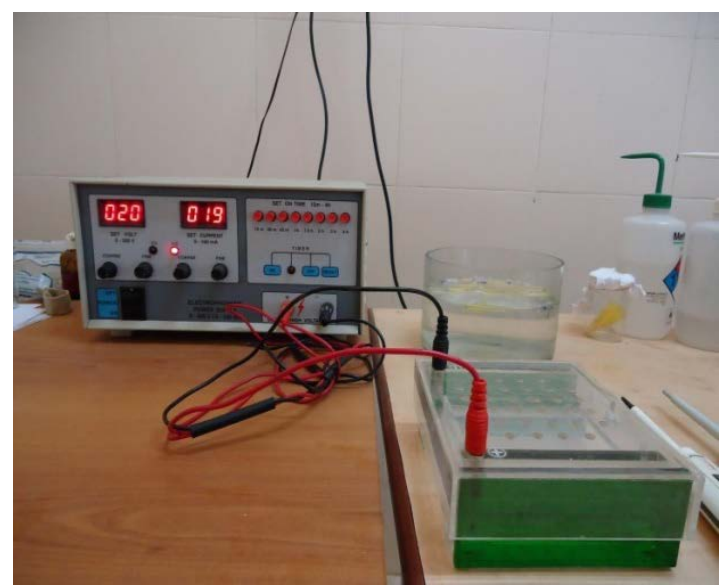

Figure 8: Agarose gel electrophoresis on their size. Selection of a primer set decides the target region to be amplified and the size of that amplified product. The primer set which was selected amplifies a base-pair fragment which is specific to blood group. The DNA ladder was run simultaneously with each gel to obtain the bands of known sizes which was used in locating the band positions of test samples [Figure 9]. The below-mentioned base pairs can be taken as a standard for determining $\mathrm{ABO}$ genotyping from pulp which has been proved in the present study: two specific bands [Table 1] (379 and $118 \mathrm{bp)}$ for A/A, three specific bands $(379,133$, and $118 \mathrm{bp}$ ) for $\mathrm{A} / \mathrm{O}$, two specific bands (224 and $118 \mathrm{bp}$ ) for $\mathrm{B} / \mathrm{B}$, four specific bands $(379,224,133$, and $118 \mathrm{bp})$ for $\mathrm{B} / \mathrm{O}$, two specific bands ( 379 and $133 \mathrm{bp}$ ) for $\mathrm{O} / \mathrm{O}$, and three specific bands $(379,224$, and $118 \mathrm{bp})$ for $\mathrm{A} / \mathrm{B}$.

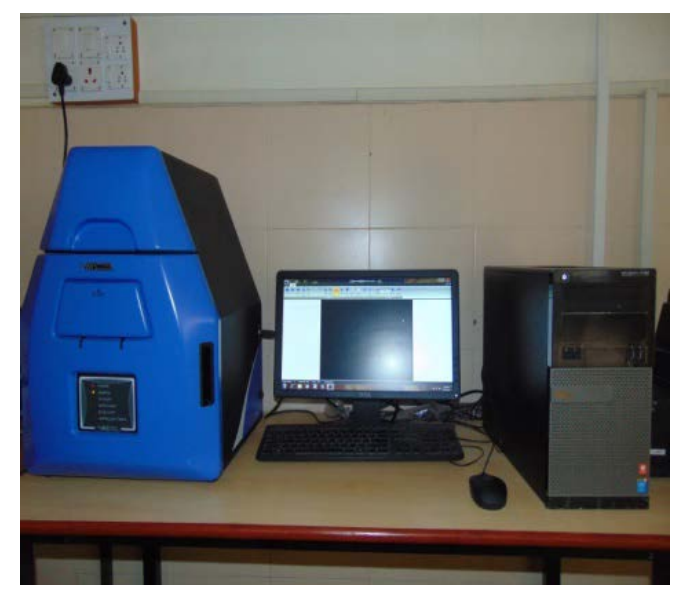

Figure 9: Gel document system

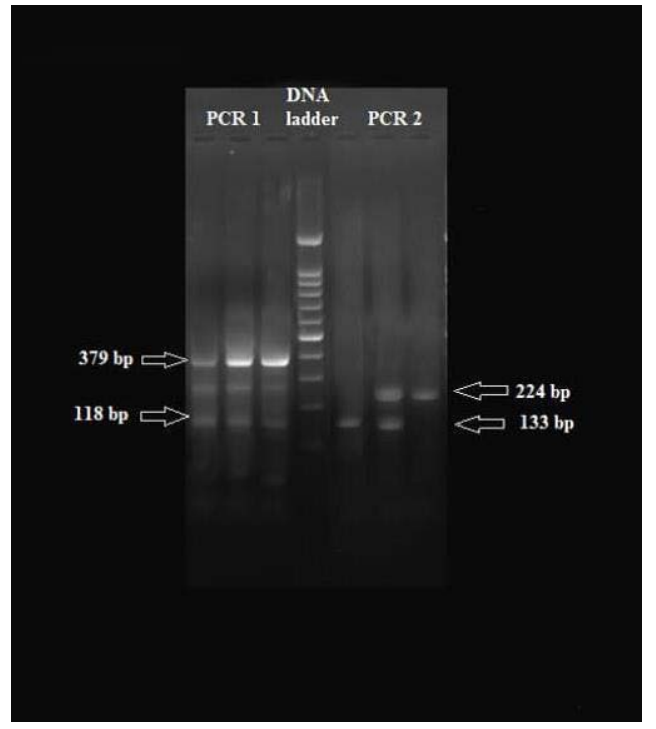

Figure 10: Gel photo of genomic DNA loaded on 1\% agarose gel 
Table 1. Allele-specific primer sets used in this study

\begin{tabular}{llcc}
\hline No. primer & Primer sequence $\left(5^{\prime} \rightarrow 3^{\prime}\right)$ & Product size $(\mathbf{b p})$ & Allele specificity \\
\hline O-261N & CAGTAGGAAGGATGTCCTCGTGGTA & 118 & O allele \\
ABO-1R3 & CTTCTTGATGGCAAACACAGTTA & & \\
ABO-1FAB2 & GAAGGATGTCCTCGTGGTG & 133 & A,B allele \\
ABO-1R & TTAACCCAATGGTGGTGTTCTGG & 224 & \\
fy-43 & GGATCCAGGGGTGCACGGCCGGCGGC & & B allele \\
$526-$ B2 & CTGCCAGCGCTTGTAGGCGTC & 379 & A,O allele \\
$526-\mathrm{A}$ & CAGCTGTCAGTGCTGGAGGTGC & & \\
Fy-2 & CCGTTGGCCTGGTCGACCATCATGGCCTG & & \\
\hline
\end{tabular}

Table 2. Blood group determination from pulp using PCR method

\begin{tabular}{|c|c|c|c|c|c|}
\hline \multirow{2}{*}{$\begin{array}{l}\text { Samples } \\
\text { (Dental pulp) }\end{array}$} & \multicolumn{2}{|c|}{ PCR 1} & \multicolumn{2}{|c|}{ PCR 2} & \multirow[t]{2}{*}{ Inference by PCR method } \\
\hline & $379 \mathrm{bp}$ & $118 \mathrm{bp}$ & $224 \mathrm{bp}$ & $133 \mathrm{bp}$ & \\
\hline 1 & + & + & + & + & $\mathrm{B}+$ \\
\hline 2 & + & + & + & - & $A B+$ \\
\hline 3 & + & - & - & + & $\mathrm{O}+$ \\
\hline 4 & + & - & - & + & $\mathrm{O}+$ \\
\hline 5 & + & + & + & + & $\mathrm{B}+$ \\
\hline 6 & - & + & + & - & $\mathrm{B}+$ \\
\hline 7 & - & + & + & - & $\mathrm{B}+$ \\
\hline 8 & - & + & + & - & $\mathrm{B}+$ \\
\hline 9 & + & + & + & + & $\mathrm{B}+$ \\
\hline 10 & + & + & - & + & $A+$ \\
\hline 11 & - & + & + & - & $\mathrm{B}+$ \\
\hline 12 & - & + & + & - & $\mathrm{B}+$ \\
\hline 13 & + & - & - & + & $0+$ \\
\hline 14 & + & + & - & + & $A+$ \\
\hline 15 & - & + & + & - & $\mathrm{B}+$ \\
\hline 16 & + & + & + & + & $\mathrm{B}+$ \\
\hline 17 & + & + & + & + & $\mathrm{B}+$ \\
\hline 18 & + & + & - & + & $\mathrm{A}+$ \\
\hline 19 & + & + & + & + & $\mathrm{B}+$ \\
\hline 20 & - & + & + & - & $\mathrm{B}+$ \\
\hline
\end{tabular}

\section{Results}

The present study was a randomized, single-blinded study consisting of 20 extracted teeth for determination ABO genotyping by PCR method, and blood groups were determined from the blood of respected samples using slide agglutination method. Both the methods of blood grouping were compared and tabulated. A paired t-test was done for concentration of DNA from pulp and dentin groups. The sensitivity and specificity were observed for ABO blood groups. 
Table 3. Blood group determination using slide agglutination method

\begin{tabular}{lcc}
\hline \multicolumn{3}{c}{ Control group(slide agglutination method) } \\
\hline Blood group & Positive (\%) & Negative (\%) \\
\hline $\mathrm{A}$ & $2(10)$ & $0(0)$ \\
$\mathrm{B}$ & $12(60)$ & $0(0)$ \\
$\mathrm{AB}$ & $1(5)$ & $0(0)$ \\
$\mathrm{O}$ & $5(25)$ & $0(0)$ \\
Total positive & $0(0)$ & $20(100)$ \\
\hline
\end{tabular}

Table 4. Blood group determination from pulp by PCR method

\begin{tabular}{lcc}
\hline Blood group & \multicolumn{2}{c}{ Study group (pulp PCR method) } \\
\cline { 2 - 3 } & Positive (\%) & Negative (\%) \\
\hline $\mathrm{A}$ & $3(15)$ & $0(0)$ \\
$\mathrm{B}$ & $13(65)$ & $0(0)$ \\
$\mathrm{AB}$ & $1(5)$ & $0(0)$ \\
$\mathrm{O}$ & $3(15)$ & $0(0)$ \\
Total positive & $0(0)$ & $20(100)$ \\
\hline
\end{tabular}

Table 5. Comparision between pulp and dentin using PCR method

\begin{tabular}{lcccc}
\hline \multirow{2}{*}{ Blood group } & \multicolumn{2}{c}{ PULP } & \multicolumn{2}{c}{ DENTIN } \\
\cline { 2 - 5 } & $\begin{array}{c}\text { Positive } \\
(\%)\end{array}$ & $\begin{array}{c}\text { Negative } \\
(\%)\end{array}$ & $\begin{array}{c}\text { Positive } \\
(\%)\end{array}$ & $\begin{array}{c}\text { Negative } \\
(\%)\end{array}$ \\
\hline A & $3(15)$ & $0(0)$ & $0(0)$ & $3(15)$ \\
B & $13(65)$ & $0(0)$ & $0(0)$ & $13(65)$ \\
AB & $1(5)$ & $0(0)$ & $0(0)$ & $1(5)$ \\
O & $3(15)$ & $0(0)$ & $0(0)$ & $3(15)$ \\
Total positive & $20(100)$ & $0(0)$ & $0(0)$ & $20(100)$ \\
\hline
\end{tabular}

Blood group determination from pulp using PCR method in 20 samples of pulp is shown in Table 2. Blood group determination from dentin using PCR method was done in 20 samples which showed negative results. Blood group determination using slide agglutination method results in percentage which is shown in Table 3. Blood group determination using PCR method showed results in percentage, as shown in Table 4. A comparison of $\mathrm{ABO}$ genotyping using PCR method between pulp and dentin is shown in Table 5. A comparison between slide agglutination method and PCR method is shown in Tables 6 and 7.

Later, the sensitivity and specificity of blood grouping from pulp PCR method was done using the formulae that showed a sensitivity of $85 \%$ and a specificity of $50 \%$.
Table 6. Comparision between slide method and PCR method

\begin{tabular}{|c|c|c|c|}
\hline $\begin{array}{l}\text { Samples } \\
\text { (Dental pulp) }\end{array}$ & $\begin{array}{l}\text { PCR method } \\
\text { (GENOTYPES) }\end{array}$ & Slide method & $\begin{array}{l}\text { Inference by } \\
\text { PCR method }\end{array}$ \\
\hline 1 & $\mathrm{~B} / \mathrm{O}$ & $0+$ & $\mathrm{B}+*$ \\
\hline 2 & $\mathrm{~A} / \mathrm{B}$ & $\mathrm{AB}+$ & $\mathrm{AB}+$ \\
\hline 3 & $\mathrm{O} / \mathrm{O}$ & $0+$ & $\mathrm{O}+$ \\
\hline 4 & $\mathrm{O} / \mathrm{O}$ & $0+$ & $\mathrm{O}+$ \\
\hline 5 & $\mathrm{~B} / \mathrm{O}$ & $0+$ & $\mathrm{B}+*$ \\
\hline 6 & $\mathrm{~B} / \mathrm{B}$ & $\mathrm{B}+$ & $\mathrm{B}+$ \\
\hline 7 & $\mathrm{~B} / \mathrm{B}$ & $\mathrm{B}+$ & $\mathrm{B}+$ \\
\hline 8 & $\mathrm{~B} / \mathrm{B}$ & $\mathrm{B}+$ & $\mathrm{B}+$ \\
\hline 9 & $\mathrm{~B} / \mathrm{O}$ & $\mathrm{B}+$ & $\mathrm{B}+$ \\
\hline 10 & $\mathrm{~A} / \mathrm{O}$ & $\mathrm{B}+$ & $\mathrm{A}+{ }^{*}$ \\
\hline 11 & $\mathrm{~B} / \mathrm{B}$ & $\mathrm{B}+$ & $\mathrm{B}+$ \\
\hline 12 & $\mathrm{~B} / \mathrm{B}$ & $\mathrm{B}+$ & $\mathrm{B}+$ \\
\hline 13 & $\mathrm{O} / \mathrm{O}$ & $0+$ & $0+$ \\
\hline 14 & $\mathrm{~A} / \mathrm{O}$ & $\mathrm{A}+$ & $A+$ \\
\hline 15 & $\mathrm{~B} / \mathrm{B}$ & $\mathrm{B}+$ & $\mathrm{B}+$ \\
\hline 16 & $\mathrm{~B} / \mathrm{O}$ & $\mathrm{B}+$ & $\mathrm{B}+$ \\
\hline 17 & $\mathrm{~B} / \mathrm{O}$ & $\mathrm{B}+$ & $\mathrm{B}+$ \\
\hline 18 & $\mathrm{~A} / \mathrm{O}$ & $\mathrm{A}+$ & $A+$ \\
\hline 19 & $\mathrm{~B} / \mathrm{O}$ & $\mathrm{B}+$ & $\mathrm{B}+$ \\
\hline 20 & $\mathrm{~B} / \mathrm{B}$ & $\mathrm{B}+$ & $\mathrm{B}+$ \\
\hline
\end{tabular}

Sensitivity is calculated by the formula: $\mathrm{A} / \mathrm{a}+\mathrm{c} \times 100$ Number of true positives(a)

$$
\begin{aligned}
& \frac{\text { Number of true positives(a) }}{\text { Number of true positives (a) }+} \times 100 \\
& \text { Number of false negatives(c) }
\end{aligned}
$$$$
\text { Sensitivity }=17 / 17+3 \times 100=85 \% \text {. }
$$

Specificity is calculated by the formula: $D / b+d \times 100$

$$
\frac{\text { Number of true negatives }(\mathrm{d})}{\text { Number of true negatives }(\mathrm{d})+} \times 100
$$

Number of false positives $(b)$

Specificity $=3 / 3+3 \times 100=50 \%$.

Inference of the study was drawn by gel photo of genomic DNA loaded on $1 \%$ agarose gel [Figure 10] which represents DNA ladder of pulp samples amplified with bright bands at $379 \mathrm{bp}$ and $118 \mathrm{bp}$ in PCR1 suggestive of positivity to A blood group and showed similar results in all three samples.

Moreover, pulp sample amplified with bright bands at $118 \mathrm{bp}$ in PCR1 and $224 \mathrm{bp}$ in PCR2 suggestive of 
Table 7. Comparison between slide agglutination method and pulp PCR method

\begin{tabular}{|c|c|c|c|c|}
\hline \multirow[t]{2}{*}{ Blood group } & \multicolumn{2}{|c|}{ Control group ( slide agglutination method) } & \multicolumn{2}{|c|}{ Study group (pulp PCR method) } \\
\hline & Positive (\%) & Negative (\%) & Positive (\%) & Negative (\%) \\
\hline A & $2(10)$ & $0(0)$ & $2(10)$ & $0(0)$ \\
\hline B & $12(60)$ & $0(0)$ & $11(60)$ & $1(5)$ \\
\hline $\mathrm{AB}$ & $1(5)$ & $0(0)$ & $1(5)$ & $0(0)$ \\
\hline $\mathrm{O}$ & $5(25)$ & $0(0)$ & $3(15)$ & $2(10)$ \\
\hline \multirow[t]{2}{*}{ Total positive } & $20(100)$ & $0(0)$ & $17(85)$ & $3(15)$ \\
\hline & \multicolumn{2}{|c|}{$20(100)$} & \multicolumn{2}{|c|}{$17(85)$} \\
\hline
\end{tabular}

positivity to B blood group showed similar results in all 13 samples. Moreover, pulp sample amplified with bright bands at $379 \mathrm{bp}$ in PCR1 and $133 \mathrm{bp}$ in PCR2 suggestive of positivity to $\mathrm{O}$ blood group showed similar results in three samples. Moreover, pulp sample amplified with bright bands at $188 \mathrm{bp}$ in PCR1 AB blood group showed similar results in one sample.

\section{Discussion}

The importance of forensic dentistry for human identification, mainly when there is little material, is left to perform identification (in decomposing bodies, explosion, fires, or skeletonized bodies), which has led dentists, working with forensic investigation to become more familiar with the new molecular biology techniques. As teeth play an important role in forensic field, extracted DNA from the pulp tissue of the tooth can be used to discriminate one individual from another individual. The use of blood group antigens in medicolegal examination is based on the fact that once a blood group is established in an individual, it remains unchanged throughout his/ her life. The presence of blood group antigens in dental tissues makes it possible to identify highly decomposed bodies where teeth and bone are the only significant tissues remaining. ${ }^{9}$ The major advantage of dental evidence is that, like other hard tissues, human teeth are very often preserved after death. ${ }^{10}$

After the discovery of $A B O$ antigens on red blood cells from serological differences in human blood by Landsteiner in 1900, the ABO blood group was classified into four antigens $(\mathrm{A}, \mathrm{B}, \mathrm{O}$, and $\mathrm{AB})$ and six genotypes (A/A, A/O, B/B, B/O, O/O, and A/B) in 1924. Furthermore, biochemical characteristics of the $\mathrm{ABO}$ antigens and structure of the $\mathrm{ABO}$ gene were elucidated. These findings have made it possible to genetically analyze $\mathrm{ABO}$ blood group antigens using molecular biology techniques. ${ }^{11}$
Blood group determination from teeth using the PCR analysis can provide an important means of personal identification in the event of mass disaster such as airplane crash or fire disasters or any other environmental conditions.

PCR is the most standardized technique in forensic field since the high rate of sensitivity and specificity has been noted in previous experiments using samples such as saliva, blood, and semen. ${ }^{9}$

PCR with sequence-specific primers of different lengths and in the present study allele-specific primers was done to determine blood group.

Originally, only $\mathrm{A}, \mathrm{B}$, and $\mathrm{O}$ could be identified, but later, methods permitted the recognition of $\mathrm{A} 1, \mathrm{~A} 2, \mathrm{~B}, \mathrm{O} 1$ (including $\mathrm{O} 1 \mathrm{v}$ ), and $\mathrm{O} 2$.

PASA method allows for the simple and rapid detection of multiple SNP sites on the ABO gene and is useful for determining the $\mathrm{ABO}$ genotype. ${ }^{11}$

A person's $\mathrm{ABO}$ type depends on the presence of two genes - the $A$ and $B$ genes. These genes are encoded on chromosome 9 (in band 9q34.1): $\mathrm{A}, \mathrm{B}, \mathrm{AB}$, or O. If a person has two A genes, their red blood cells are type A. If a person has two $B$ genes, their red cells are type B. If the person has one $A$ and one $B$ gene, their red cells are type $\mathrm{AB}$. If the person has neither the $\mathrm{A}$ nor $\mathrm{B}$ gene, they are type $\mathrm{O} .{ }^{12}$

Kumar et al. conducted a study on 150 cases to determine blood groups and Rhesus factor from dentin and pulp using absorption elution technique in different time periods at $0,3,6,9$, and 12 months. The dentin and pulp of extracted teeth were tested for the presence of $\mathrm{ABO} / \mathrm{Rh}$ antigen, and a study stated that both $\mathrm{ABO}$ and $\mathrm{Rh}$ factor, dentin, and pulp showed a $100 \%$ sensitivity for the samples tested at 0 month and showed a gradual decrease in the sensitivity as time period increased, and in comparison with the above study, the present study has showed a $100 \%$ sensitivity for the all the pulp samples and 
PCR can be considered as higher end when compared to other methods because less amount of DNA is required for amplification. ${ }^{12}$

In comparison with the studies done by Sood et al. and Viaykumar et al., ABO blood group determination in the present study was using specific alleles for blood groups, which is considered to be a signature gene to differentiate different blood groups using PCR method. Present study included 20 teeth in which isolation of DNA was possible in all the samples of pulp and dentin using Modified Proteinase-K method for Pulp and Phenol/chloroform organic extraction for Dentin. Blood grouping from pulp was possible in all samples but from dentin it was not possible as the quantity and purity of DNA from dentin samples were not optimal; other rigorous DNA isolation methods need to be adopted to get ideal DNA quantity from dentin samples. Hence, PCR was not processed with dentin samples.

Roshale Gaytmenn et al. conducted a study on 250 teeth and were sectioned. Later, DNA quantification was done utilizing the AluQuant ${ }^{\mathrm{im}}$, and results showed that there is a sufficient quantity of DNA in crown body and root body. Moreover, in the present study, DNA was isolated using modified proteinase-K method (Qiagen Multiplex PCR Kit) for pulp using Qiagen Multiplex PCR Kit containing $\times 10$ PCR buffer (containing 15 $\mathrm{mM} \mathrm{MgCl} 2$ ), dNTP mix $10 \mathrm{mM}$ of each, and Taq DNA polymerase 2.5 units/reaction. ${ }^{13}$

Pai et al. conducted a study in 50 exfoliated primary teeth which were stored in soil for 6 months, and DNA extraction was carried out. Sixty-six percent of samples showed a DNA yield. They stated that $100 \%$ results were obtained for samples studied at $\mathrm{pH} 4$ and $\mathrm{pH} 7$, whereas samples stored at $\mathrm{pH} 10$ showed $10 \%$ result. Seawater and buried samples showed $80 \%$ and $40 \%$ results, respectively. Thirty-three teeth out of 50 showed positive results with $66 \%$ success using pulp by PCR and control group showed $100 \%$ results, and in comparison with the above study, samples were not stored in any environmental conditions and DNA isolation was done immediately from tooth. Pulp and dentin showed $100 \%$ for isolation of DNA, and $85 \%$ showed positive results for blood grouping with PCR method. ${ }^{9}$

In the present study, results from $\mathrm{ABO}$ genotyping through PCR showed as 13 were B blood group, 3 were $\mathrm{O}$ blood group, 3 were $\mathrm{A}$ blood group, and 1 was $\mathrm{AB}$ blood group. In comparison of blood grouping between PCR method and slide agglutination method, 17 samples showed similar results in both methods and 3 samples did not match with slide agglutination method and PCR method. Because the genotype expressed, allele can be dominant or recessive in three samples.

In our study, a comparison between both methods, slide agglutination method showed $100 \%$ positive results and PCR showed $85 \%$ positive results for pulp and $100 \%$ negative results for dentin. Blood grouping from dentin was not possible as the quantity and purity of DNA from dentin samples were not optimal; other rigorous DNA isolation methods need to be adopted to get ideal DNA quantity from dentin samples. Hence, PCR was not processed with dentin samples.

\section{Conclusion}

Determination of blood group is an important step in personal identification in forensic sciences. The present study has found that DNA retrieval can be done from human teeth for forensic caseworks. The above mentioned base pairs can be taken as a standard for determining $\mathrm{ABO}$ genotyping from pulp which has been proved in the present study.

\section{Financial Support and Sponsorship}

Nil.

\section{Conflicts of Interest}

There are no conflicts of interest.

\section{References}

1. Singh K, Anandani C, Bhullar RK, Agrawal A, Chaudhary $\mathrm{H}$, Thakral A. Teeth and their secrets-forensic dentistry. J Forensic Res 2012;3:9-11.

2. Zakirulla M, Meer A. Modern tools in forensic dentistry. Int J Contemp Dent 2011;2:28-32.

3. Verma AK, Kumar S, Rathore S, Pandey A. Role of dental expert in forensic odontology. Natl J Maxillofac Surg 2014;5:2-5. 
4. Karthika B, Elumalai M. Identity of blood group from dental pulp of deceased Human. Int J Pharm Bio Sci 2013;4:1000-4.

5. Kumar MG, Hegde AM. Sex identification from exfoliated primary teeth - A PCR study. J Clin Pediatr Dent 2005;30:19-21.

6. Xingzhi X, Ji L, Hao F, Ming L, Zhuyao L. ABO blood grouping on dental tissue. J Forensic Sci 1993;38:956-60.

7. Lijnen I, Willems G. DNA research in forensic dentistry. Methods Find Exp Clin Pharmacol 2001;23:511-7.

8. Woolridge ED, Jr. Forensic dentistry. In: Eckert WG, editor. Introduction to Forensic Science. 2nd ed. St. Louis: The C.V. Mosby Company; 1980. p. 114-7.

9. Pai KR, Tellis R, Afreen S. Blood group determination using DNA extracted from exfoliated primary teeth at various environmental conditions - A PCR study. IJAR 2014;2:639-47.
10. Khan R, Tejasvi MLA, Paramkusam G. Comparison of gender determination from dental pulp and dentin after exposure to various environmental conditions: A polymerase chain reaction-based SRY gene study. Contemp Clin Dent 2019;10:256-62.

11. Aki K, Kawazoe K, Izumi A, Tada T. Direct determination of $\mathrm{ABO}$ blood group genotypes from whole blood using PCR-amplification of specific alleles method. Am J Bio Sci 2014;2:49-55.

12. Kumar PV, Vanishree M, Anila K, Hunasgi S, Suryadevra SS, Kardalkar S. Determination of ABO blood grouping and Rhesus factor from tooth material. J Oral Maxillofac Pathol 2016;20:540-4.

13. Corte-Real A, Andrade L, Anjos M, Carvalho M, Vide M, Corte-Real F, et al. Genetic identification in endodontic treated tooth root. Forensi Sci Int Gene Suppl 2008;130:1-2.

How to cite this article: Lakshmi $B$, Tejasvi AML. $A B O$ genotyping from pulp and dentin using DNA: A polymerase chain reaction study. J Forensic Dent Sci 2020;12(1):1-9.

\begin{tabular}{|l|c|}
\hline \multicolumn{2}{|c|}{ Access this article online } \\
\hline \multirow{3}{*}{ Website: } & Quick Response Code \\
\cline { 2 - 2 } www.jfds.org & \\
& \\
& \\
&
\end{tabular}

